Revue bibliographique pour le domaine irano-aryen

\title{
Christelle Jullien. « Traditions croisées sur les trois enfants dans la fournaise (Dn III)»
}

\section{Marie-Joseph Pierre}

\section{Q OpenEdition}

1 Journals

\section{Édition électronique}

URL : http://journals.openedition.org/abstractairanica/42594

DOI : 10.4000/abstractairanica.42594

ISBN : 1961-960X

ISSN : 1961-960X

Éditeur :

CNRS (UMR 7528 Mondes iraniens et indiens), Éditions de l'IFRI

Référence électronique

Marie-Joseph Pierre, « Christelle Jullien. «Traditions croisées sur les trois enfants dans la fournaise

(Dn III) » », Abstracta Iranica [En ligne], Volume 37-38-39 | 2018, document 1, mis en ligne le 10 mars 2018, consulté le 02 octobre 2020. URL : http://journals.openedition.org/abstractairanica/42594 ;

DOI : https://doi.org/10.4000/abstractairanica.42594

Ce document a été généré automatiquement le 2 octobre 2020.

Tous droits réservés 


\title{
Christelle Jullien. « Traditions croisées sur les trois enfants dans la fournaise (Dn III) »
}

\author{
Marie-Joseph Pierre
}

\section{RÉFÉRENCE}

Christelle Jullien. « Traditions croisées sur les trois enfants dans la fournaise (Dn III) », in : M. Bais, Carlo Cereti, Mariacarmela Benvenuto (eds.), Nāme-ye Irān-e Bāstān, The International Journal of Ancient Iranian Studies (special issue) 12/1-2, 2014, p. 135-152.

1 Examen de l'épisode des trois enfants dans la fournaise de l'épisode biblique du Livre de Daniel (chapitre III) dans les traditions religieuses juive et chrétienne (spécialement dans les Actes des martyrs perses) relatives à leurs reliques en territoire iranien.

\section{AUTEURS}

\section{MARIE-JOSEPH PIERRE}

Directrice d'Études honoraire, EPHE 